\title{
Research on Auto Parts Industry Upgrading Based on Internet of Things
}

\author{
Chen Caiyuan ${ }^{1, *}$ and Wang Long ${ }^{2}$

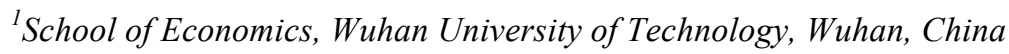

\begin{abstract}
Based on the importance of development and upgrading of auto parts industry, the article analyzes the location of auto parts industry. In order to achieve further development and upgrade, five factors influencing China auto parts industry upgrading are put forward afterwards in this paper. They are market demands, resource supply, technology level, system and policy and international trade. An empirical analysis is made by multivariate statistical regression methods and testifies the result of qualitative analysis above and then gets the quantitative conclusion.
\end{abstract}

Keywords: Auto parts industry, industry upgrading, empirical analysis, multivariate statistical regression, qualitative and quantitative analysis.

\section{INTRODUCTION}

Auto parts has been playing an increasingly important role in the automotive industry as the basis for the automotive industry [1]. Auto parts industry is the premise and foundation to enhance the competitiveness of automotive industry in general [2]. Auto parts industry which has high permeability with other industry can promote the development of related product industry including a number of industries of steel, instruments, plastic and glass [3]. In the global automotive industry value chain, auto parts worth about $50 \%$ of total value chain. Automobile and parts industry played a crucial role for the development of the country. Auto parts industry as the most important part in automobile industry chain which is in the upper reaches of the automobile industry chain has increased the competitive landscape of the auto parts industry with the global procurement of automobile companies [4]. Auto parts industry upgrading has become increasingly urgent with the background of increasingly competitive automobile industry. Automobile companies have a series of changes for "large and all" to "small but fine" and become more and more professional. The way of MMC reduces the self-rate of components, so the original dependency between vehicle and parts business has undergone changes which means auto parts industry has must change also [4].

The current way is part of mainstream business and automobile companies to establish long-term stability of the market based on the guidelines of the strategic partnership. Auto parts industry production has changed from geographical specialization of the division of labor to shift further accelerate the pace of industrial transfer to transfer low-cost countries [6]. The rapid development of auto parts industry faces some challenges. There appear some factors which affect industrial development including rising resource prices and labor costs and a series factors of financial crises [5]. It is a must to make timely adjustments and donduct industrial upgrading [7], otherwise the development of auto parts industry will be hindered. Therefore, it is very important to reasearch and study the factors which affect the auto parts industry and start from the key factors to use the limited resources in order to break out and improve the weakness [8]. The more important thing is to maximize the initiative to promote the development of auto parts industry upgrading and form the production management system supporting the automobile market $[9,10]$.

The rest of the paper is organized as follows. In Section 2 , overview of auto-parts industry is summarized briefly. In Section 3, reasearch of auto-parts industry upgrading is described. In Section 4, empirical analysis are presented and the results are discussed. Finally, a conclusion is provided in Section 5.

\section{OVERVIEW OF AUTO-PARTS INDUSTRY}

As shown in (Fig. 1), the development trends of auto parts industry are very obvious including the following four aspects: (1) Acceleration of international industrial transfer and merger activity. It is predicted that there are about 5,500 major auto parts companies in the world, but of which more than 2000 enterprises will be eliminated. Also the top 20 firms who dominate the world automotive market share will rise from the current level of $27 \%$ to $50 \%$. These changes will push the process of worldwide auto parts industry of mergers and restructuring which will reduce the number of first-level suppliers. (2) Technical standardization of auto parts, electronics and intelligent. Auto parts with standardization and common is the basis for industrial production and improve versatility of parts which will make the best component sharing as possible and thereby expand the scale of production of parts to reduce the high costs due to the evershortening product life cycle of automobile. The main products of auto parts have been changing from mechanical de- 
vices to consumer electronics products. (3) Modular grading supply system. Automobile factory increasingly tends to a modular and systematic procumbent. It's more closely for collaboration between suppliers and make auto parts plant to reduce the number of parts to form a new assembly module. Global automotive supplier system gradually evolved pagoda structure including three distinct levels: plant is responsible for the whole supply chain management in the first level and parts supplier is to become the second and third suppliers which make cooperation between the supply chain more standardized. (4) Trends in cluster development. From the point of view of industrial structure, the automobile industry is a complete organic production system with vehicle manufacturing, component manufacturing and automotive services. Its features of long industry and many associated industry determine the advantages of cluster of automobile industry.

Despite the development of auto parts is rapid, there also exists some problems. a) It's so difficult to form scale of auto parts industry due to the irrational structure. $b$ ) There is not enough funding for research and development, then the technology is very low and independent innovation capability is not strong. c) Parts industry and automobile industry development are not in synch which restricts the development of parts industry. d) Parts industry is not concentrated and it is difficult to form cluster.

\section{REASEARCH OF AUTO-PARTS INDUSTRY UP- GRADING}

Auto parts industry upgrading includes the upgrading of industrial structure.

1) Industry level. Upgrading in industrial level is mainly from the upgrade of industrial structure to technology upgrades and then to the position as shown in (Fig. 2).

2) Enterprise level. Firm-level upgrade is mainly from the upgrade of manufacturing system to enterprise technology upgrades and then to enterprise brands as shown in (Fig. $3)$.

Under the premise of a smooth embedding in the global value chain, the strategy for future development of China's auto parts industry should be like this. Government guides local parts companies to break through on the value chain governance patterns through the development of relevant industrial policies and adjust its connection with the global value chain in order to seek greater development space of China's auto parts industry.

In addition to government industrial policy support, Chinese parts companies which as the subject of innovation policy and practice and implementation of value chain governance patterns should enhance the supply capacity by the way of increasing the strategic investments, strategic reorganization, entering new markets and new value chain.

\section{EMPIRICAL ANALYSIS ON THE AUTO PARTS INDUSTRY UPGRADING}

\subsection{Basic Model and Variable Selection of Empirical Analysis}

(1) Basic model.

Cobb-Douglas function can be used to study the relationship between inputs and outputs in a country or region. We used this economics of mathematical models to study labour and capital which inputs on the progress and development of China's auto parts industry. The basic model is as follows:

$Y=A_{\mathrm{t}} L^{\alpha}{ }^{\alpha}{ }^{\beta} \mu$

When $\alpha+\beta>1$, it is increasing returns industry that it is benefical to expand the scale of production to increase economic output for technology. It is opposite when $\alpha+\beta<1$. In the case of $\alpha+\beta=1$, it shows that productivity is not rose in tandem with the expansion of production scale and we can increase economic efficiency only by improving the technical level.

ADF test is used to verify if the time series is stationary. Stationary time series can construct a regression model and other econometric models. Non-stationary time series is to have a smooth sequence by differential elimination unit root, it will return the regression analysis that is pseudo. Two delay difference regression model is as follows:

$$
\Delta Y_{t}=\beta_{1} Y_{t-1}+\beta_{2} \Delta Y_{t-1}+\beta_{2} \Delta Y_{t-2}+\beta_{4}+\beta_{5} t+e_{t}
$$

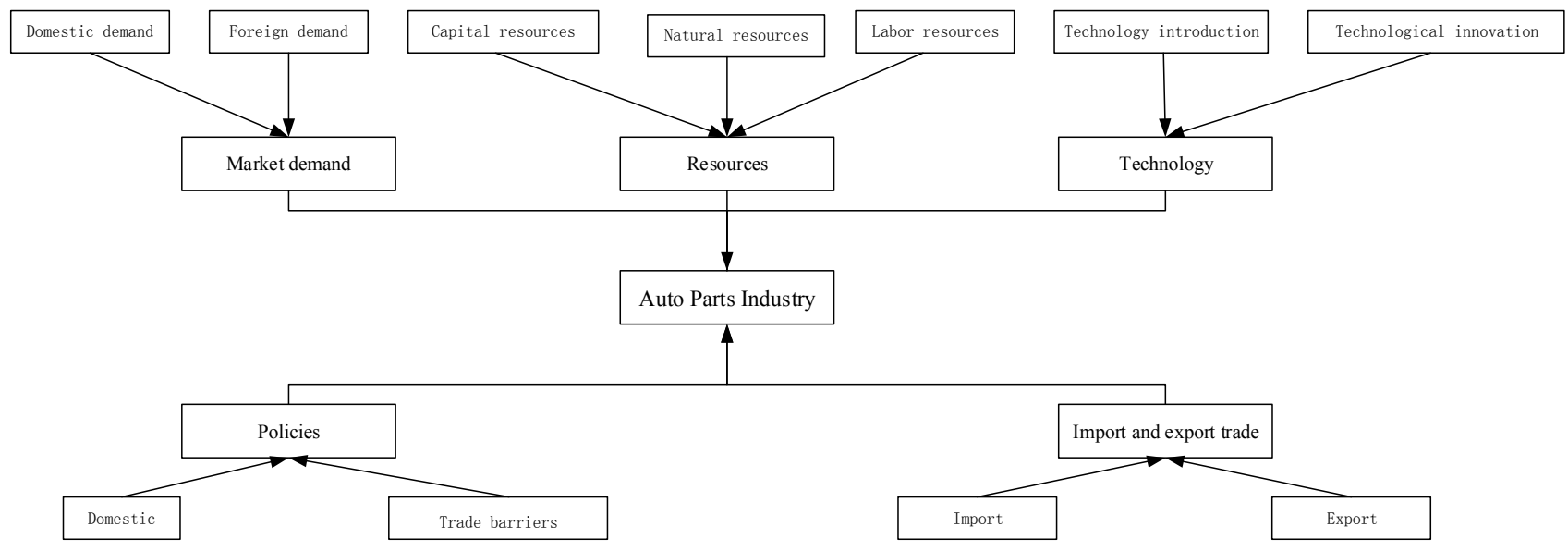

Fig. (1). Factors affecting the auto parts industry upgrading. 


\begin{tabular}{|c|c|c|}
\hline Upgrading of industrial structure & Upgrading of industrial technology & Upgrading of industrial position \\
\hline$\nabla$ & $\nabla$ & $\downarrow$ \\
\hline $\begin{array}{l}\text { - Specialization and scale } \\
\text { - Integration of total and } \\
\text { Individual } \\
\text { - Industry concentration }\end{array}$ & $\begin{array}{l}\text { - The ability of independent } \\
\text { innovation } \\
\text { - Quality system certification } \\
\text { - Modular development capabilities }\end{array}$ & $\begin{array}{l}\text { The ability of independent } \\
\text { innovation } \\
\text { - Active participation in national and } \\
\text { international division }\end{array}$ \\
\hline
\end{tabular}

Fig. (2). Auto parts industry upgrade path.

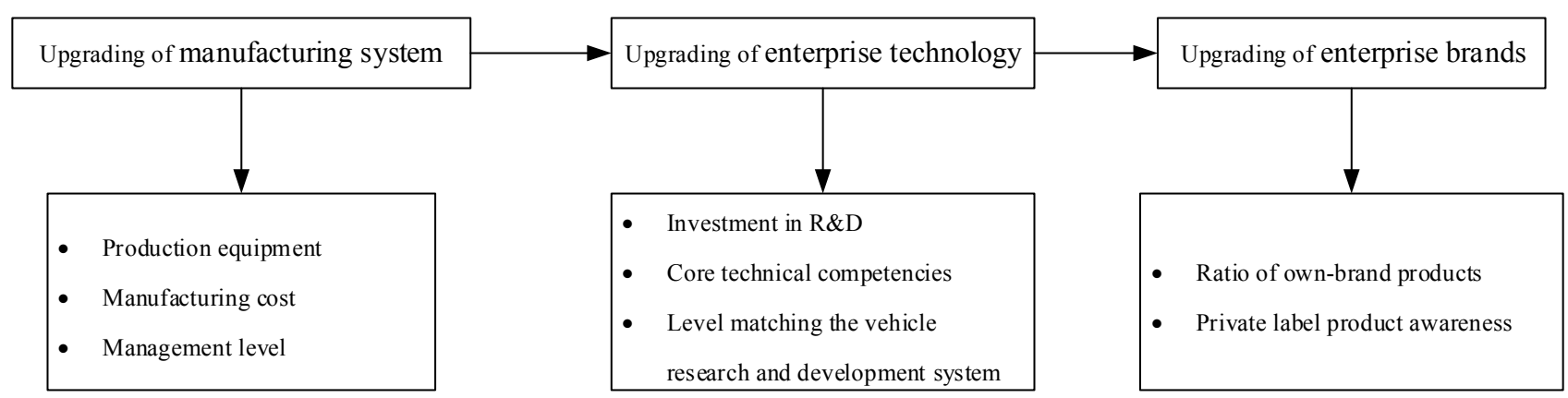

Fig. (3). Auto parts enterprise upgrade path.

(2) variable selection

The article chooses quantifiable variables to conduct empirical analysis on China's auto parts industry upgrading. 1) The explained variable $Y$. The article selected indicators of value chain upgrading of industrial added value in consideration. 2) Capital input $K$. It is indicated by fixed capital investments in auto parts industry. 3) Labour input
$L$. This article assumes that the labor force is equal to the total number of employed persons. 4) Technological innovation $R$. Technological progres is representative of the amount of investment in research and development. 5) Degree of external trade $Z$. The article selected the total import and export volume to reflect. 6) Degree of marketization $M$.

Table 1. Variable unit root test results.

\begin{tabular}{|c|c|c|c|c|c|}
\hline Variable & ADF & $(\mathbf{c}, \mathbf{t}, \mathbf{n})$ & Critical Value of $1 \%$ & Critical Value of $5 \%$ & Stationarity \\
\hline InY & 3.177 & $(0,0,0)$ & -4.800 & -3.791 & No \\
\hline $\mathrm{D}(\operatorname{In} \mathrm{Y})$ & -3.796 & $(0,0,0)$ & -2.740 & -1.968 & Yes \\
\hline In $\mathrm{K}$ & -2.813 & $(0,0,0)$ & -4.800 & -3.791 & No \\
\hline $\mathrm{D}(\operatorname{In} \mathrm{K})$ & -4.722 & $(0,0,0)$ & -2.728 & -1.966 & Yes \\
\hline In $\mathrm{L}$ & 1.547 & $(0,0,0)$ & -2.728 & -1.966 & No \\
\hline $\mathrm{D}(\operatorname{In~L})$ & -2.032 & $(0,0,0)$ & -2.754 & -1.791 & Yes \\
\hline In $\mathrm{R}$ & -2.025 & $(0,0,0)$ & -4.800 & -3.791 & No \\
\hline $\mathrm{D}(\operatorname{In} \mathrm{R})$ & -3.965 & $(\mathrm{c}, \mathrm{t}, 0)$ & -4.886 & -1.970 & Yes \\
\hline In $Z$ & 1.488 & $(0,0,0)$ & -2.754 & -1.970 & No \\
\hline $\mathrm{D}(\operatorname{In} Z)$ & -4.011 & $(0,0,0)$ & -4.886 & -3.828 & Yes \\
\hline In M & -1.234 & $(0,0,0)$ & -4.059 & -3.118 & No \\
\hline $\mathrm{D}(\mathrm{In} \mathrm{M})$ & -2.809 & $(0,0,0)$ & -2.754 & -1.970 & Yes \\
\hline
\end{tabular}


Table 2. Cointegration test.

\begin{tabular}{|c|c|c|c|c|}
\hline $\begin{array}{c}\text { Hypothesized } \\
\text { No. Of CE(s) }\end{array}$ & Ejgenvalue & $\begin{array}{c}\text { Trace } \\
\text { Statistic }\end{array}$ & $\begin{array}{c}\text {.05 } \\
\text { Critical Value }\end{array}$ & Prob. \\
\hline \hline None & 0.992484 & 82.76715 & 29.79707 & 0.0000 \\
\hline At most 1 & 0.634763 & 14.29747 & 15.49471 & 0.0052 \\
\hline At most 2 & 0.442770 & 6.811968 & 3.841466 & 0.0041 \\
\hline
\end{tabular}

\subsection{Results}

This article will use the Eviews6.0 measuring software to conduct empirical analysis for development of China's auto parts industry and its influencing factors and verify the impact and contribution of these factors on China's auto parts industry development. Test results are presented in (Table $\mathbf{1}$ and 2).

$\mathrm{D}(\ln \mathrm{Y})$ represents the first-order difference of InY. The c, $\mathrm{t}$ and $\mathrm{n}$ represents the intercept term, trend and lag order. From the data above, we can get:

$$
\begin{aligned}
& \operatorname{In} Y=-6.62+0.563 \operatorname{In} L+0.814 \operatorname{In} K \\
& \operatorname{In} Y=3.242+3.082 \operatorname{In} R \\
& \operatorname{In} Y=14.295+2.05 \operatorname{In} M \\
& \operatorname{In} Y=-11.172+5.456 \operatorname{In} Z
\end{aligned}
$$

The article conducts empirical analysis of the five factors, results are shown in (Fig. 4 and 5).

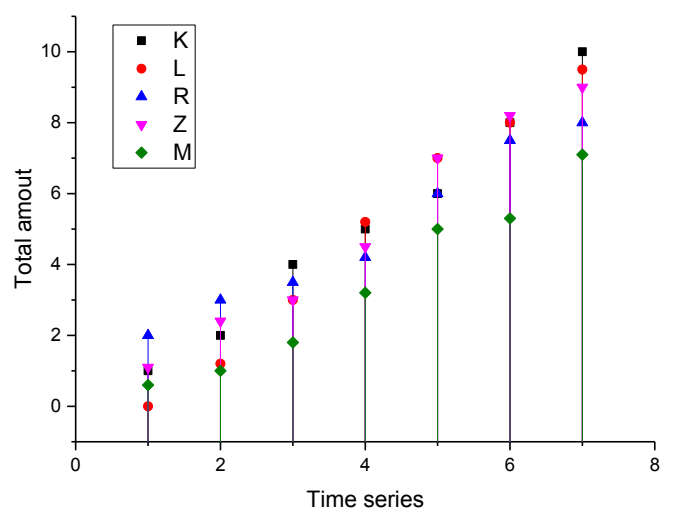

Fig. (4). Drop line of empirical analysis of factors.

From the results presented above, resources of capital and labor inputs, the degree of technological progress, trade and market-oriented upgrades on the auto parts industry has more or less influence. Capital resources and impact of labour input in the two comparison shows that while capital and labor resources upgrade on the auto parts industry has a positive role. Capital investment will contribute significantly to upgrading automobile parts industry. Based on high extraversion, foreign investment of auto parts industry plays the important role and increases the financial support.

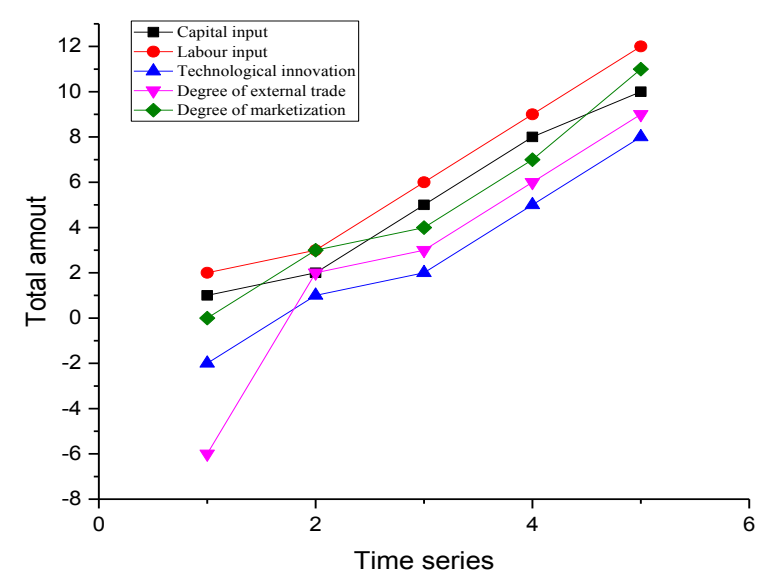

Fig. (5). Results of empirical analysis of factors.

\section{CONCLUSION}

Technological progress is a strong boost to development of automobile parts industry with long-term stability and relevance. Auto parts industry is still shown as increasing scale enterprises. Investment in research and development will strengthen technical innovation and the core technology means we can take control of the core and a high added value links in the industrial value chain to improve the subordination of value chain and speed up industrial development and upgrading greatly.

It is desirable to further apply empirical analysis to solving those more complex real-world optimization problems and it will be our further work.

\section{CONFLICT OF INTEREST}

The authors confirm that this article content has no conflicts of interest.

\section{ACKNOWLEDGEMENTS}

This work is supported by education department project "performance measurement of achievement of university" (EFA090413).

\section{REFERENCES}

[1] R.A. Corredoira, G.A. McDermott, "Adaptation, bridging and firm upgrading: How non-market institutions and MNCs facilitate knowledge recombination in emerging markets", Journal of International Business Studies, vol. 45, no. 6, pp. 699-722, 2014. 
[2] J. Humphrey and H. Schmitz, "How does insertion in global value chains affect upgrading in industrial clusters?" Regional Studies, vol. 9, no. 36, pp. 1017-1027, 2002.

[3] J. Humphrey and H. Schmitz, Development Country Firms in the World Economy: Governance and Upgrading in Global Value Chains, INEF: INEF-Report, pp. 121-124, 2002.

[4] J. Jin, X. Dai and E. Zhang, "The path for china's industry upgrading under global factors division", China Industrial Economics, vol. 11, p. 005, 2013.

[5] Y.S. Li, X. Kong, M. Zhang, "Industrial upgrading in global production networks: the case of the Chinese automotive industry" Asia Pacific Business Review, pp. 1-17, 2014.

[6] T.S.C. Poon, "Beyond the global production networks: a case of further upgrading of Taiwan's information technology indus- try", Technology and Globalization, vol. 1, no. 1, pp. 150-145, 2004.

[7] P. Pavlinek, B. Domanski, R. Guzik, "Industrial upgrading through foreign direct investment in Central European automotive manufacturing", European Urban Regional Studies, vol. 16, no. 1, pp. 4363, 2009.

[8] E.D. Peters, "The auto parts-automotive Chain in Mexico and China: co-operation potential?", The China Quarterly, vol. 209, pp. 82$110,2012$.

[9] Y. Wang, X. Xiao, Y. Zhou, "Research on service mode of auto parts technology innovation based on the industrial chain", Proceedings of the 21st International Conference on Industrial Engineering and Engineering Management 2014, Atlantis Press, 2015, pp. 163-166.

[10] W. Yi, "Research on green upgrade of Shanghai automobile industry", Scientific Development, pp. 8-13, 2013.

(C) Caiyuan and Long.; Licensee Bentham Open.

This is an open access article licensed under the terms of the Creative Commons Attribution Non-Commercial License (http://creativecommons.org/licenses/by$\mathrm{nc} / 3.0 /$ ) which permits unrestricted, non-commercial use, distribution and reproduction in any medium, provided the work is properly cited. 